\title{
Di(1H-benzo[d][1,2,3]triazol-1-yl)methane: An efficient ligand for copper and amine-free palladium-catalysed Sonogashira coupling reaction
}

\author{
JASPAL SINGH and AKHILESH KUMAR VERMA* \\ Synthetic Organic Chemistry Research Laboratory, Department of Chemistry, University of Delhi, \\ Delhi 110007, India \\ e-mail: averma@acbr.du.ac.in
}

\begin{abstract}
An efficient Pd-catalysed Sonogashira coupling reaction was achieved in the absence of copper and amine with inorganic base using phosphene-free, air stable di(1H-benzo[ $d][1,2,3]$ triazol-1-yl)methane as ligand. The cross coupling of electron-rich, electron-defficient and hindered aryl halides with terminal alkynes afforded the internal alkynes in good to excellent yields.
\end{abstract}

Keywords. Palladium; terminal alkynes; benzotriazole; amine-free; copper-free.

\section{Introduction}

Transition metal-catalysed reactions play an important role in the synthesis of various organic substrates, natural products and pharmaceutically viable molecules. ${ }^{1}$ Among all the metals, palladium has emerged as a powerful tool ${ }^{2}$ for the cross coupling reaction like Heck, Negishi, Suzuki and Sonogashira coupling reactions. ${ }^{3}$ The conjugated $\pi$ systems resulting from alkynylation reactions are building blocks often encountered within natural products, pharmaceutical molecules, synthetic agrochemicals, and molecular materials. ${ }^{4,5}$ During last decade Sonogashira reaction has become one of the most widely used method for the synthesis of aryl or vinyl acetylenes from aryl or vinyl halides and terminal alkynes.

Many applications of Sonogashira coupling of aryl halides with terminal alkynes have been reported in the literature since $1975 .^{5,6}$ A large number of efforts have been directed to explore new catalytic systems. The most common catalytic system for this reaction is the combination of palladium and phosphines such as $\mathrm{PdCl}_{2}\left(\mathrm{PPh}_{3}\right)_{2}, \mathrm{PdCl}_{2} / \mathrm{PPh}_{3}$, and $\mathrm{Pd}\left(\mathrm{PPh}_{3}\right)_{4}$ with $\mathrm{CuI}$ as the co-catalyst and amines as the solvents under degassed condition. ${ }^{7}$ Successful examples include replacement of triphenylphosphine with some special phosphines to enhance the catalytic efficiency. ${ }^{8}$ However, many phosphine ligands are airsensitive and expensive, resulting in significant limits on their synthetic applications. ${ }^{9}$ Furthermore, the presence of $\mathrm{CuI}$ can result in the formation of some $\mathrm{Cu}(\mathrm{I})$ acetylides in situ that can readily undergo oxidative

\footnotetext{
${ }^{*}$ For correspondence
}

homocoupling reaction of acetylenes. ${ }^{10}$ To overcome these drawbacks, many phosphine and copper-free palladium-catalysed Sonogashira coupling protocols have been developed. ${ }^{11}$ Recently a copper-free Sonogashira cross-coupling reaction was reported using combination of phosphine and amine along with large amount of tetra- $n$-butyl ammonium salt as an activator. $^{12 \mathrm{a}, \mathrm{c}}$ Recently, Mino et al. described hydrazone ligands for such cross-coupling. ${ }^{12 \mathrm{~b}}$ Development of an efficient, inexpensive, copper-, phosphine- and aminefree catalytic system is considerable. In continuation of our efforts on the designing of benzotriazole based ligands for the coupling reactions, and synthetic elaboration of heterocycles by using palladiumcatalysed coupling reactions, ${ }^{13 \mathrm{a}-\mathrm{h}}$ here we are reporting $\operatorname{Di}(1 H$-benzo $[d][1,2,3]$ triazol-1-yl)methane (L4) as new air-stable and phosphine-free ligand for palladium-catalysed Sonogashira cross-coupling reaction without using copper and amine (scheme 1).

\section{Experimental}

\subsection{General procedure for Sonogashira} cross-coupling reaction of terminal alkynes with aryl halides

A flask was charged with $\mathrm{Pd}(\mathrm{OAc})_{2}(3 \mathrm{~mol} \%), \mathbf{L 4}$ (6 $\mathrm{mol} \%$ ) and $1.0 \mathrm{mmol}$ of aryl halide in $1.5 \mathrm{~mL}$ of DMSO. After stirring at room temperature for $15 \mathrm{~min}$, terminal alkyne (1.5 equiv.) and $\mathrm{K}_{2} \mathrm{CO}_{3}$ (2.5 equiv.) were added to the flask, and the reaction mixture was stirred at $80^{\circ} \mathrm{C}$ for $10-12 \mathrm{~h}$. After completion of 


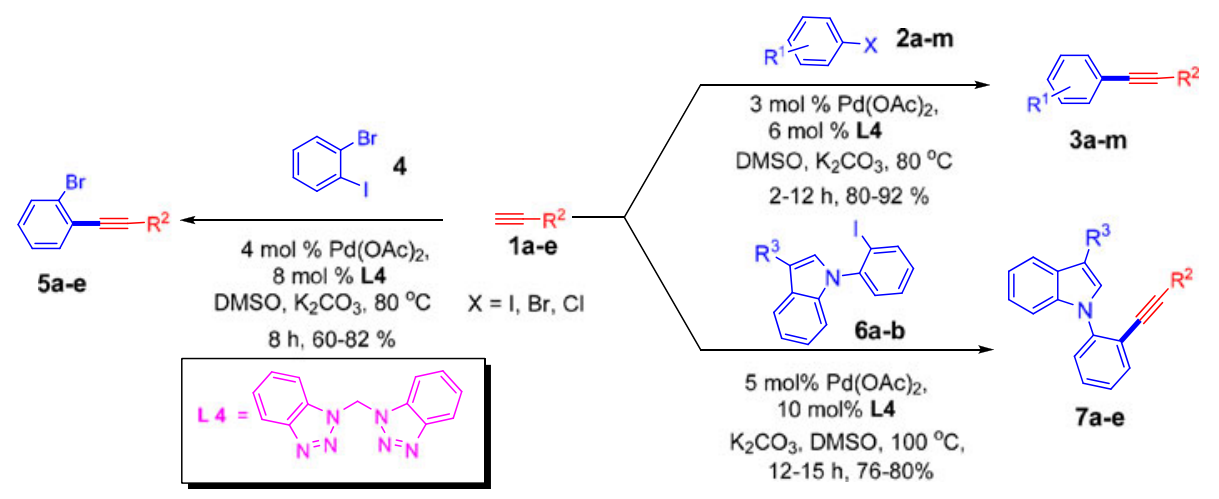

Scheme 1. Sonogashira coupling reaction using di(1H-benzo[d][1,2,3]triazol-1-yl)methane $(\mathbf{L 4})$.

reaction as indicated by thin-layer chromatography (TLC), water $(10 \mathrm{~mL})$ was added to the reaction mixture. It was then extracted with ethyl acetate $(2 \times 10 \mathrm{~mL})$. The combined organic layer was dried over anhydrous $\mathrm{Na}_{2} \mathrm{SO}_{4}$ and was concentrated under reduced pressure. The crude was then purified by column chromatography on silica gel (100-200 mesh) using petroleum ether/ethyl acetate (98:2) as eluent to afford the desired pure products.

\section{Results and discussion}

Firstly, with the above precedents in mind, in order to optimize the reaction conditions we undertook an intensive screening of variety of ligands and reaction variables. We first chose electron-rich $p$-bromoanisole (2a) and penylacetylene (1a) as model reaction to screen the catalyst systems to optimize the reaction conditions. Initially, a series of ligands, benzotriazole and its

Table 1. Optization of Sonogashira reaction conditions. ${ }^{\mathrm{a}}$

\begin{tabular}{|c|c|c|c|c|c|}
\hline Entry & Solvent & $\begin{array}{l}\text { Temp } \\
\left({ }^{\circ} \mathrm{C}\right)\end{array}$ & $\begin{array}{l}\text { Ligand } \\
\text { (L) }\end{array}$ & Base & $\begin{array}{l}\text { Yield } \\
(\%)^{\mathrm{b}}\end{array}$ \\
\hline 1 & DMF & 80 & L1 & $\mathrm{K}_{2} \mathrm{CO}_{3}$ & 38 \\
\hline 2 & $\mathrm{DMF}$ & 80 & L2 & $\mathrm{K}_{2} \mathrm{CO}_{3}$ & 45 \\
\hline 3 & DMF & 80 & L3 & $\mathrm{K}_{2} \mathrm{CO}_{3}$ & 20 \\
\hline 4 & DMF & 80 & L4 & $\mathrm{K}_{2} \mathrm{CO}_{3}$ & 85 \\
\hline 5 & DMF & 60 & L4 & $\mathrm{K}_{2} \mathrm{CO}_{3}$ & 62 \\
\hline 6 & DMF & 80 & L4 & $\mathrm{Na}_{2} \mathrm{CO}_{3}$ & 45 \\
\hline 7 & DMF & 80 & L4 & pyridine & trace \\
\hline 8 & DMF & 80 & L4 & $\mathrm{Et}_{3} \mathrm{~N}$ & 65 \\
\hline 9 & DMF & 80 & L4 & $\mathrm{Cs}_{2} \mathrm{CO}_{3}$ & 78 \\
\hline 10 & DMF & 80 & L4 & $\mathrm{KOH}$ & trace \\
\hline 11 & DMF & 80 & L4 & $\mathrm{KO} t \mathrm{Bu}$ & trace \\
\hline 12 & $\mathrm{CH}_{3} \mathrm{CN}$ & 80 & L4 & $\mathrm{K}_{2} \mathrm{CO}_{3}$ & 68 \\
\hline 13 & Dioxane & 80 & L4 & $\mathrm{K}_{2} \mathrm{CO}_{3}$ & 38 \\
\hline 14 & DME & 80 & L4 & $\mathrm{K}_{2} \mathrm{CO}_{3}$ & 60 \\
\hline 15 & DMA & 80 & L4 & $\mathrm{K}_{2} \mathrm{CO}_{3}$ & 75 \\
\hline 16 & DMSO & 80 & L4 & $\mathrm{K}_{2} \mathrm{CO}_{3}$ & 90 \\
\hline
\end{tabular}

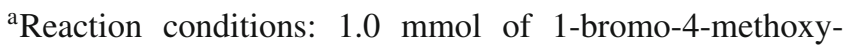
benzene $2 \mathbf{a}, 1.5 \mathrm{mmol}$ of phenylacetylene 1a, 2.5 equiv. of base, $3 \mathrm{~mol} \%$ of $\mathrm{Pd}(\mathrm{OAc})_{2}, 6 \mathrm{~mol} \%$ of ligand and $1.5 \mathrm{~mL}$ of solvents. ${ }^{\mathrm{b}}$ Isolated yield 
derivatives (L1-L4) were examined (table 1, entries 1-4). It was found that without ligand less than $10 \%$ of the desired cross-coupling product 3a was obtained, along with $40 \%$ homo-coupling product of the phenylacety- lene. The addition of benzotriazole (L1) enhanced the yield of the coupling product 3a up to $38 \%$ (table 1, entry 1 ). In order to achieve the best results in crosscoupling reaction, three derivatives of benzotriazole,

Table 2. $\operatorname{Pd} / \mathbf{L} \mathbf{4}$ catalysed cross-coupling reaction of alkynes with aryl halides. ${ }^{\mathrm{a}}$
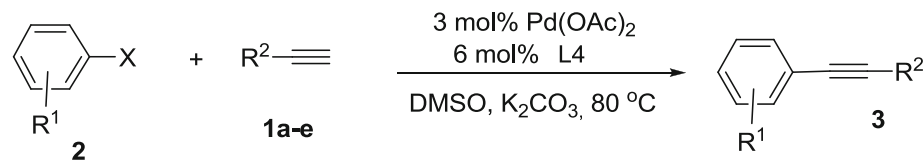

Entry

${ }^{a}$ Reaction conditions: $1.0 \mathrm{mmol}$ of aryl halides, $1.5 \mathrm{mmol}$ of terminal alkyne, 2.5 equiv. of $\mathrm{K}_{2} \mathrm{CO}_{3}, 3 \mathrm{~mol} \%$ of $\mathrm{Pd}(\mathrm{OAc})_{2}, 6 \mathrm{~mol} \%$ of Ligand $\mathbf{L} 4$, and $1.5 \mathrm{~mL}$ of DMF at $80^{\circ} \mathrm{C}, 10-12 \mathrm{~h}$. ${ }^{\mathrm{b}}$ Isolated yield. ${ }^{\mathrm{c}}$ Reaction was carried out at $80^{\circ} \mathrm{C}$ for $2-4 \mathrm{~h}$. ${ }^{\mathrm{d}}$ Reaction was carried out at $110^{\circ} \mathrm{C}$ for $15 \mathrm{~h}$.

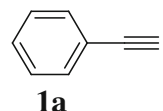

$1 \mathbf{a}$

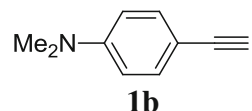

$1 \mathrm{~b}$

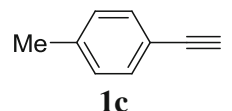

$1 c$

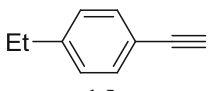

1d 
having more electron density and probable binding site, 1- $H$-benzotriazolylmethanol L2, 1-( $(1 H$-imidazol-1yl)methyl)- $1 H$-benzo[ $d][1,2,3]$ triazole $\mathbf{L 3}$, and $\operatorname{di}(1 \mathrm{H}-$ benzo[d][1,2,3]triazol-1-yl)methane $\mathbf{L} \mathbf{4}$, were tested as ligands and were found more effective than ligand $\mathbf{L 1}$ in the cross-coupling reaction (table 1 , entries 2,3 , and 4). It was observed that in a series of reactions with $3 \mathrm{~mol} \%$ of $\mathrm{Pd}(\mathrm{OAc})_{2}$ and $6 \mathrm{~mol} \%$ of ligand $\mathbf{L 2}, \mathbf{L 3}$ and $\mathbf{L} 4$ in DMF at $80^{\circ} \mathrm{C}$ using 2.5 equiv $\mathrm{K}_{2} \mathrm{CO}_{3}$, coupling product 3a was obtained in 45, 20 and $85 \%$ yields respectively (table 1, entries 2, 3 and 4). Product 3a was obtained in $62 \%$ yield at $60^{\circ} \mathrm{C}$ (table 1 , entry 5 ). It is evident from the table 1 that ligand $\mathbf{L} \mathbf{4}$ was found more effective than ligand L1, L2 and L3. A significant effect of bases was found in the reaction. When $\mathrm{Na}_{2} \mathrm{CO}_{3}$ was used as a base 3a was obtained only in $45 \%$ yield (table 1, entry 6 ). Pyridine was found ineffective; however $\mathrm{Et}_{3} \mathrm{~N}$ afforded the coupling product in $65 \%$ yield under these reaction conditions (table 1 , entries 7 and 8). $\mathrm{Cs}_{2} \mathrm{CO}_{3}$ afforded the coupling product in $78 \%$ yield (table 1, entry 9). With strong bases such as $\mathrm{KOH}$ and $\mathrm{KO} t \mathrm{Bu}$, trace amount of the coupling product was obtained (table 1 , entries 10 and 11). It can be observed from the table 1 that amongst the bases tested (table 1, entries 4, 6-11), $\mathrm{K}_{2} \mathrm{CO}_{3}$ was found most suitable and amongst various solvents DMSO was proved to be the best solvent (table 1, entries 4, 12-16).

Subsequently, selected terminal alkynes 1a-d, were reacted with various aryl iodides and bromides 2a-l under the optimized reaction conditions (table 2). All the aryl halides with electron-releasing and electronwithdrawing groups were successfully coupled with terminal alkynes and afforded the corresponding crosscoupling products in $80-92 \%$ yields. It is noteworthy that a variety of functional groups (nitro, keto, bromo, and aldehydic) substituted aryl halides tolerate the reaction condition, and afforded the coupling products in good yields in short reaction time using low catalyst loading (3 mol\%).

It is interesting to note that the reaction of aryl iodides with 2a, were very rapid at high temperature $\left(80^{\circ} \mathrm{C}\right)$ and gave excellent yields of the desired products in 2-4 h (table 2, entries 1, 3, and 6), while the substituted alkynes $\mathbf{1 b}-\mathbf{d}$, having electron releasing

Table 3. $\mathrm{Pd} / \mathbf{L} \mathbf{4}$ catalysed selective cross-coupling reaction of alkynes with $o$-iodobromobenzene. $^{\mathrm{a}}$

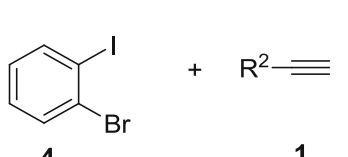

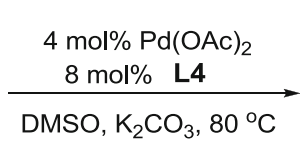

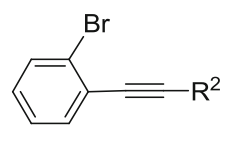

5

Entry

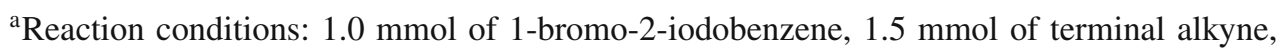
2.5 equiv. of $\mathrm{K}_{2} \mathrm{CO}_{3}, 4 \mathrm{~mol} \%$ of $\mathrm{Pd}(\mathrm{OAc})_{2}, 8 \mathrm{~mol} \%$ of Ligand $\mathbf{L 4}$, and $1.5 \mathrm{~mL}$ of DMSO at $80^{\circ} \mathrm{C}$ for $8 \mathrm{~h}$. ${ }^{\mathrm{b}}$ Isolated yield. 

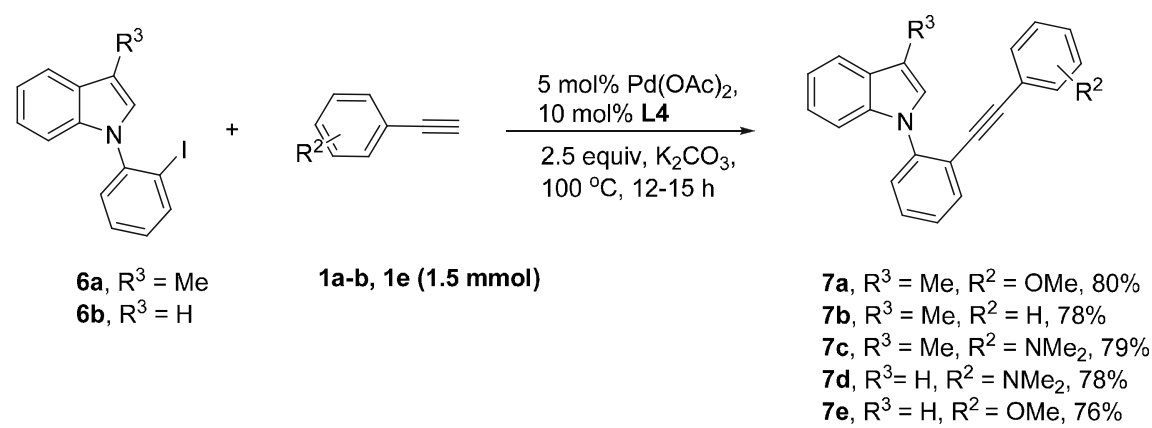

Scheme 2. Sonogashira coupling reaction of 1-(2-iodophenyl)-1H-indole $\mathbf{6 a - b}$.

substituent, afforded the desired coupling products in longer duration (table 2, entries 12-16). The efficacy of the catalyst system was also tested on aryl chloride $\mathbf{2 m}$, and it was found that the reaction of aryl chloride with 1a gave the desired product $3 \mathbf{a}$ in $45 \%$ yield at $110^{\circ} \mathrm{C}$ after $15 \mathrm{~h}$.

Furthermore, the optimized combination of $\mathrm{Pd}(\mathrm{OAc})_{2}$ and $\mathbf{L} \mathbf{4}$ was further tested with 1-bromo-2iodobenzene $\mathbf{4}$ and terminal alkynes $\mathbf{1 a - b}, \mathbf{1 e - g}$. It is evident from the table 3 that the reaction outcome was not much affected by the steric hindrance derived from the ortho-substituents (table 3, entries 4 and 5).

Having the results on coupling of aryl halides and 1-bromo-2-iodobenzene benzenes in our hand, we further investigated the coupling of more difficult and large molecules 1-(2-iodophenyl)- $1 H$-indoles $\mathbf{6 a - b}$ as shown in scheme 2. Fortunately, the results indicated that the present catalyst system also displayed the high catalytic activity to catalyse the cross-coupling of terminal alkynes 1a-c with 1-(2-iodophenyl)- $1 H$-indole 6a-b using $5 \mathrm{~mol} \%$ of $\mathrm{Pd}(\mathrm{OAc})_{2}, 10 \mathrm{~mol} \%$ of $\mathbf{L} \mathbf{4}$ and afforded the coupling products $7 \mathbf{a}-\mathbf{e}$ in $76-80 \%$ yields at $110^{\circ} \mathrm{C}$.

\section{Conclusion}

In summary, we have developed a general method for rapid Sonogashira cross-coupling reaction of aryl halides with terminal alkynes using $\mathrm{Pd}(\mathrm{OAc})_{2}$ and $\operatorname{di}(1 H$-benzo $[d][1,2,3]$ triazol-1-yl)methane $(\mathbf{L 4})$ as new air stable and inexpensive ligand. The advantage of this protocol includes omission of copper, easy handling of catalyst and high catalytic activity for electronpoor as well as electron-rich aryl halides under mild and convenient conditions. Further investigations to expand the scope of the designed ligands are ongoing and will be reported in due course.

\section{Supporting information}

Characterization data and copies of ${ }^{1} \mathrm{H}$ and ${ }^{13} \mathrm{C}$ NMR spectra of all the synthesized compounds are given as electronic supporting information (see www.ias.ac.in/chemsci).

\section{Acknowledgements}

We gratefully acknowledge the Department of Science and Technology (DST), Council of Scientific and Industrial Research (CSIR), New Delhi, and University of Delhi, Delhi for the financial support. JS is thankful to CSIR, for the SRF.

\section{References}

1. Reviews on transition metal catalysed reactions, see: (a) Magano J and Dunetz J R 2011 Chem. Rev. 1112177 and references cited therein; (b) Chen X, Engle K M, Wang D and Yu J Q 2009 Angew. Chem. Int. Ed. 48 5094; (c) Ackermann L, Vicente R and Kapdi A R 2009 Angew. Chem. Int. Ed. 48 9792; (d) Nakamura I and Yamamoto Y 2004 Chem. Rev. 104 2127; (e) Gladysz J A 2011 Chem. Rev. 1111167

2. (a) Martin R and Buchwald S L 2008 Acc. Chem. Res. 41 1461; (b) Fu G C 2008 Acc. Chem. Res. 41 1555; (c) Chinchilla R and Njera C 2007 Chem. Rev. 107 874; (d) Molnar A 2011 Chem. Rev. 111 2251; (e) Islam S M, Mondal P, Tuhinab K and Roya A S 2010 J. Chem. Technol. Biotechnol. 85999 and references cited therein

3. (a) Suzuki A 2011 Angew. Chem. Int. Ed. 50 6722; (b) Negishi E I 2011 Angew. Chem. Int. Ed. 50 6738; (c) Wu X F, Anbarasan P, Neumann H and Beller M 2010 Angew. Chem. Int. Ed. 49 9047; (d) Niphakis M J and Georg G I 2011 Org. Lett. 13 196; (e) Ioannidou H A, Kizas C and Koutentis P A 2011 Org. Lett. 13 3466; (f) Proutiere F and Schoenebeck F 2011 Angew. Chem. Int. Ed. 508192

4. (a) Paterson I, Davies R D M and Marquez R 2001 Angew. Chem. Int. Ed. 40 603; (b) Yoshimura F, Kawata S and Hirama M 1999 Tetrahedron Lett. 40 8281; (c) Graham A E, McKerrecher D, Davies D H and Taylor R J K 1996 Tetrahedron Lett. 37 7445; (d) Nicolaou K C and Dai W M 1991 Angew. Chem. Int. Ed. Engl. 30 
1387; (e) Maier M E 1995 Synlett. Issue 1 13; (f) Grissom J W, Gunawardena G U, Kingberg D and Huang D 1996 Tetrahedron 52 6453; (g) Bunz U H F 2000 Chem. Rev. 100 1605; (h) Tour J M 2000 Acc. Chem. Res. 33 791; (i) Brunsveld L, Meijer E W, Prince R B and Moore J S 2001 J. Am. Chem. Soc. 1237978

5. For reviews, see the following: (a) Sonogashira, K. In Metal-catalyzed cross-coupling reactions 1998; F Diederich and P J Stang (eds); New York: Wiley-VCH; Chapter 5; pp 203; (b) Doucet H and Hierso J C 2007 Angew.Chem. Int. Ed. 46 834; (c) Chinchilla R and Najera C 2007 Chem. Rev. 107 874; (d) Negishi E I and Anastasia L 2003 Chem. Rev. 1031979

6. (a) Sonogashira K, Tohda Y and Hagihara N 1975 Tetrahedron Lett. 16 4467; (b) Cassar L 1975 J. Organomet. Chem. 93 253; (c) Dieck H A and Heck F R 1975 J. Organomet. Chem. 93259

7. For selected papers on the palladium/phosphine/CuI/ amine system for the Sonogashira cross-coupling reactions, see: (a) Thorand S and Krause N 1998 J. Org. Chem. 63 8551; (b) Hundertmark T, Litter A F, Buchwald S L and Fu G C 2000 Org. Lett. 2 1729; (c) Hierso J C, Fihri A, Amardeil R and Meunier P 2004 Org. Lett. 6 3473; (d) Novák Z, Szabó A, Répási J and Kotschy A 2003 J. Org. Chem. 68 3327; (e) Son S U, Jang Y, Park J, Na H B, Park H M, Yun H J, Lee J and Hyeon T 2004 J. Am. Chem. Soc. 126 5026; (f) Adjabeng G, Brenstrum T, Frampton C S, Robertson A J, Hillhous J, McNulty J and Capretta A 2004 J. Org. Chem. 69 5082; (g) Elangovan A, Wang Y H and Ho T I 2003 Org. Lett. 5 1841; (h) Remmele H, Köllhofer A and Plenio H 2003 Organometallics 22 4098; (i) Batey R A, Shen M and Lough A 2002 Org. Lett. 4 1411; (j) Lee D H, Jung J Y and Jin M J 2010 Green. Chem. 12 2024; (k) Roy S and Plenio H 2010 Adv. Synth. Catal. 3521014

8. For selected papers on $\mathrm{Pd} /$ Ligand and copper free conditions (a) Choudary B M, Madhi S, Chowsari N S, Kantam M L and Sreedhar B 2002 J. Am. Chem. Soc. 124 14127; (b) Herrmann W A 2002 Angew. Chem., Int. Ed. 41 1290; (d) Nájera C, Gil-Moltó J, Karlström S and Falvello L R 2003 Org. Lett. 5 1451; (e) Soheili A, Albaneze-Walker J, Murry J A, Dormer P G and Hughes D L 2003 Org. Lett. 5 4191; (f) Rau S, Lamm K, Goerls H, Schoeffel J and Walther D 2004 J. Organomet. Chem. 689 3582; (h) Alonso D
A, Botella L, Najera C and Pacheco M C 2004 Synthesis 10 1713; (j) Wolf C and Lerebours R 2004 Org. Biomol. Chem. 22 161; (1) Fukuyama T, Shinmen M, Nishitani S, Sato M and Ryu I 2002 Org. Lett. 4 1691; (m) Böhm V P and Hermann W A 2000 Eur. J. Org. Chem. Issue 22 3679; (n) Méry D, Heuzé K and Astruc D 2003 Chem. Commun. Issue 15 1934; (o) Nájera C, Gil-Moltó J, Karlström S and Falvello L R 2003 Org. Lett. 5 1451; (p) Alonso D A, Nájera C and Pacheco M C 2003 Adv. Synth. Catal. 345 1146; (q) Ngassa F N, Gomez J M, Haines B E, Ostach M J, Hector J W, Hoogenboom L J and Page C E 2010 Tetrahedron 66 7919; (r) Chen H J, Lin Z Y, Li M Y, Lian R J, Xue Q W, Chung J L, Chen S C and Chen Y J 2010 Tetrahedron 66 7755; (s) Fleckenstein C A and Plenio H 2008 Green. Chem. 10 563; (t) Islam S M, Mondal P, Roy A S, Mondal S and Hossain D 2010 Tetrahedron Lett. 51 2067; (u) Kuang Y Y and Chen F E 2009 Helv. Chim. Acta 92897

9. Pignolet L H (ed) 1983 Homogeneous catalysis with metal phosphine complexes, New York; Plenum

10. (a) Siemsen P, Livingston R C and Diederich F 2000 Angew. Chem. Int. Ed. 39 2632; (b) Li J H, Liang Y and Zhang X D 2005 Tetrahedron 611903

11. (a) Li J H, Zhang X D and Xie Y X 2005 Eur. J. Org. Chem. Issue 20 4256; (b) Liang Y, Xie Y X and Li J H 2006 J. Org. Chem. 71 379; (c) Yi C and Hua R 2006 J. Org. Chem. 712535

12. (a) Liang B, Dai M, Chen J and Yang Z $2005 \mathrm{~J}$. Org. Chem. 70 391; (b) Mino T, Shirae Y, Saito T, Sakamoto M and Fujita T 2006 J. Org. Chem. 71 9499; (c) Komaromi A and Novak Z 2008 Chem. Commun. Issue 404968 and references therein

13. (a) Verma A K, Singh J, Sankar V K, Chaudhary R and Chandra R 2007 Tetrahedron Lett. 48 4207; (b) Verma A K, Singh J and Chaudhary R 2007 Tetrahedron Lett. 48 7199; (c) Verma A K, Kesharwani T, Singh J, Tandon V and Larock R C 2009 Angew. Chem., Int. Ed. 39 2632; (d) Verma A K, Singh J and Larock R C 2009 Tetrahedron 65 8434; (e) Jha R R, Chaudhary R, Chandra R and Verma A K 2011 J. Indian Chem. Soc. 88 1; (f) Verma A K, Rustagi V, Aggarwal T and Singh A P 2010 J. Org. Chem. 75 7691; (g) Verma A K, Joshi M and Singh V P 2011 Org. Lett. 13 1630; (h) Verma A K, Shukla S P, Singh J and Rustagi V 2011 J. Org. Chem. 765670 